\title{
Preservice Science Teachers' Misconceptions About Evolution
}

\author{
Ayla Karataş \\ Correspondence: Ayla Karataş, Kocaeli Üniversitesi, Faculty of Education, Turkey. \\ Received: June 9, 2019 \\ Accepted: January 9, 2020 \\ Online Published: January 17, 2020 \\ doi:10.11114/jets.v8i2.4690 \\ URL: https://doi.org/10.11114/jets.v8i2.4690
}

\begin{abstract}
Misconceptions/misunderstandings are a basic problem often encountered in topics in education. "Misunderstandings" commonly observed about evolution makes it difficult for biology teachers to teach this topic. Reasons that are related to teachers are a basic source of misconceptions. Misconceptions can increase incrementally if their source is teachers. This study aims to determine the nature and scope of nonscientific views about evolution in preservice science teachers. An important step in correcting misconceptions or misunderstandings is to first determine the frequently observed misunderstandings. This study investigates and compares the misconceptions of students who have completed an evolution course and those who have not. The results showed that an evolution course considerably decreased the misconceptions. The most frequently observed misconceptions were; considering evolution as the effort to bring living things to perfection, associating evolution only with Darwin, identifying evolution with metamorphosis, thinking that living things evolve to accommodate, and having only a human-focused perspective about evolution. The idea that believing in evolution is an alternative to believing in a creator; that it is not possible for someone to believe in a creator and, at the same time in evolution, or vice versa also appeared as a noteworthy misconception revealed by the study.
\end{abstract}

Keywords: evolution education, misconception, preservice science teachers

\section{Introduction}

Evolution, which examines the origins of living organisms and their genetic connections, and explains the underlying reasons of common characteristics and differences observed in living beings, is the most striking and meaningful theme of the living world (Dobzhanzky, 1973). It is not possible to understand biology without understanding evolution, by reason that it is the sole theory which meaningfully combines the knowledge related to all domains of biology (Futuyma, 2008; Freeman \& Herron, 2002; Lerner, 2000; Tidon \& Lewontin, 2004). In addition to the in-depth understanding of the various domains of biology, a mutual interaction in other sciences like mathematics, geology and philosophy is needed in order to understand evolutionary biology as well. Teachers have a significant role in the transition of knowledge in these domains (Tidon \& Lewontin, 2004). In order to popularize the scientific perspective of evolution in an accurate way, the role of secondary and high school teachers is especially important. Anderson (2007) has indicated that it is of significance to be first aware of teacher views regarding evolution and to evaluate their confidence in teaching evolutionary concepts, in order to make recommendations on evolutionary theory in different cultures and educational systems.

Any mistake in the transition or learning of knowledge causes problems in the construction of further knowledge. For this reason, misunderstanding or misconception is a noteworthy instructional issue. Misunderstanding/misconception is defined as "any conceptual idea different from the generally accepted scientific consensus" (Garnett \& Treagust, 1990). Results have emerged indicating that biology students in colleges and universities do not learn as much as their instructors think. The number of undergraduate biology students with scientifically inaccurate ideas has become a particular source of concern (Bishop \& Anderson, 1990; Nehm \& Reilly, 2007a). Both teachers and students learn what is meaningful to them, even it is incorrect. Misconceptions generally result in critical future learning problems. Scientifically inaccurate ideas in the long-term memory affect the perception and interpretation of new knowledge because these previous ideas create a basis for interpreting and making sense out of affective inputs. Misconceptions related to biology continue from secondary education through university and affects the basis of understanding of science (Coll \& Treagust, 2003). Studies have reported that both teachers and preservice teachers have misconceptions about particular topics in biology (Burgoon et al., 2011). Global studies on the education of evolution have shown that non-scientific ideas (generally labeled "misconceptions") about the topic of evolution are frequent at every education level (e.g., Moore et al., 2006; BouJaoude et al., 2011; Kagan \& Sanders, 2013). Miller (2006) has indicated that one 
possible reason behind society's low-level acceptance of evolution could be the lack of understanding of biological concepts. Besides the public's extensive lack of understanding about evolution (Abraham et al., 2009), a large number of misconceptions about biological evolution has been stated (Alters \& Alters 2001; Miller, 2006). The scope of these misconceptions can vary from minor misunderstanding to ones completely rejecting the theory (Alters \& Alters 2001; Dagher \& BouJaoude 2005; Evans 2001; Mazur 2004; McComas, 1994, McComas 2006; Sadler 2005).

This study took the views of preservice teachers who did or did not participate in a comprehensive course about evolution and investigated the misconceptions. Even if secondary education is included in compulsory education, some students do not have to take biology-based courses which make it important to teach the fundamentals and process of evolution at a cognitively appropriate and basic level within the scope of the secondary education school science course. Finding new and innovative ways of detecting and clearing up misconceptions teachers might possess in order to improve science education is necessary (Burgoon et al., 2011). Therefore, this study investigated evolution-related misconceptions of preservice science teachers who have a significant role at diverse education levels from primary to high school. With this purpose in mind, preservice science teachers' views/thoughts about evolution were collected and their misconceptions were identified.

\section{Method}

Preservice teachers' views about evolution were collected by requiring them to complete sentences with their own ideas. This study is a qualitative study and the motive behind using this method is to reveal preservice science teachers' misconceptions through open-ended statements about evolution. This technique was designed adapting two techniques; free word association (Kurt et al., 2013) and metaphor technique (Y1lmaz, 2016).Data were collected using a worksheet requiring them to complete the sentence "To me, evolution is because " (Karataş, 2019).

With this open-ended sentence structure, data were collected on students' views about evolution and reasons behind these views. In most test techniques, students need to select one of the available options. However, in this method, students are encouraged to write their personal views about evolution and the reason behind this view. Considering the data obtained by the sentence structure, students' views about evolution were collected under certain themes and published as a separate article (Karatas, 2019). Students' in-depth responses were further analyzed and their misconceptions about evolution were revealed. Results were collected and analyzed under different groups of misconceptions.

\subsection{Participants}

For this study, science education undergraduate students were selected because the more misconceptions observed in the preservice teachers, the more efficient it is to detect these misconceptions, as it passes on through education by way of teachers.

Data were collected from 190 preservice teachers in the Science Education Department of the Educational Faculty of a university. The evolution course is compulsory in the eighth term of the program of the science education department. The same curriculum is administered in all educational faculties in Turkey; a different curriculum is not used due to a regional variation. All of the participating preservice teachers are Muslims. The study group consisted of senior preservice teachers who completed the evolution course, and sophomores and juniors who have not taken the course yet. The aim of collecting data from students who completed or did not complete the course is both to determine misconceptions and to reveal the effect of completing a comprehensive education process on misconceptions. Data were collected from a total of 190 students, of whom 91 were senior preservice teachers who completed the course and 99 sophomores and juniors who did not participate in the course. These fundamental topics were taught in the evolution course: geological evolution process, the importance of within species variance, natural selection, effect types of natural selection, adaptation, genetics of population, factors altering genetics of population (microevolution factors), the biological species term and speciation, barriers to speciation, geographical isolation and allopatric speciation, macroevolution, sympatric speciation, speciation through autopolyploid and allopolyploid, and mutations and the mutation of developmental genes, in particular. The content knowledge is of critical importance for teaching evolution. The complete teaching of all these a fore mentioned topics is performed in only a period of one term, these fundamental topics can be taught over a period of 14 weeks. The data were collected after the senior preservice teachers completed the course and from other students (sophomores and juniors) at the end of the spring term.

\subsection{Validity and Reliability}

In order to ensure the validity of the study, the students who did and did not participate in the evolution course were included in the study. Thus, data triangulation was provided (Merriam, 2009) and, therefore, a comparative analysis was applied to the misconceptions of the students who did and did not take the course. Also, by including direct excerpts of 
the data about misconceptions, readers were provided the opportunity to see the raw data. Therefore, they were given the opportunity to make their own inferences and interpretations (Yıldırım \& Simsek, 2008; Merriam, 2009).

\section{Results}

Misconceptions were detected in 57 of the 190 preservice teachers participating in the study, which corresponds to $30 \%$ of the students. This misconception rate is a considerably high rate observed on a particular topic. However, the vast majority of this rate $(43.43 \%)$ was the misconceptions encountered in the students who have never taken an evolution course. The sophomores and juniors have not taken the evolution course yet and possessed a high rate of misconceptions (Table 1). Even though there are major area courses related to biology and evolution-related ideas in these courses from time to time, a high number of misconceptions were encountered in this group of preservice teachers (Table 1). The same table showed the rate of misconceptions for the senior preservice teachers decreased considerably after they completed the evolution course. However, as seen in Table 1, there were still misconceptions observed also among the students who completed the evolution course. 14 out of 91 students had misconceptions even though they completed the course. Despite the decrease in the number of misconceptions among the students completing the course, the misconceptions were not fully cleared up; however, it is accurate to state that their frequency dropped. Table 2 shows the number of misconceptions and some example sentences.

Table 1. Distribution of misconceptions

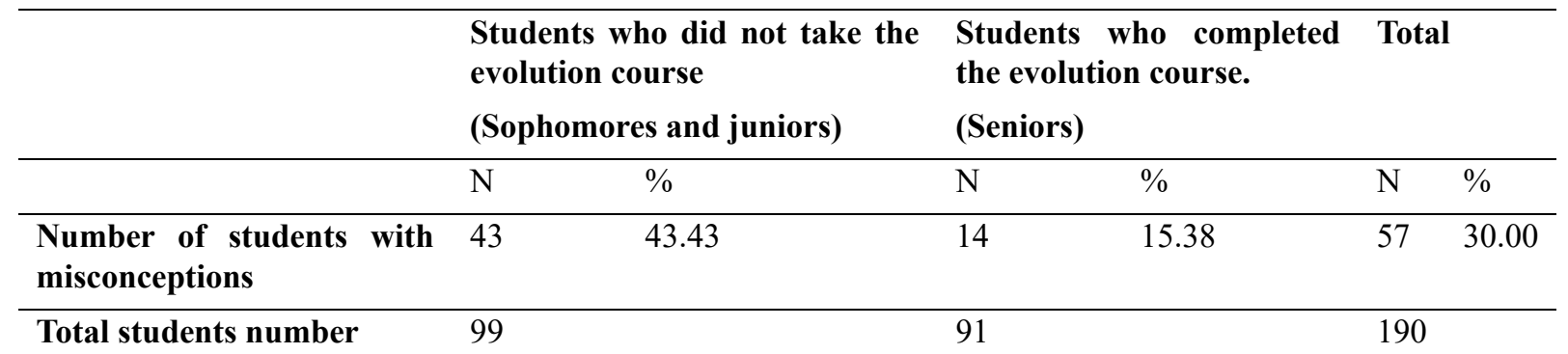

The misconception that evolution always occurs towards the stronger, better and more perfect was one of the most frequently observed misconceptions. Evolution was perceived as a process where the strong survive, and will achieve near perfection, and the weak will surely be eliminated (Table 2).

The students' sole human-focused perspective of evolution was the second most encountered misconception. It is a striking result that only human evolution is mentioned, which is actually effective in the diversification of all living beings on this planet. In addition to this, the statement that humans came into existence from apes was another misconception.

Another misconception is the idea that living beings change throughout life in order to comply with changing environmental conditions. The proposition that an organism changes when conditions change in order to adapt is extremely in accurate. A large number of misconceptions were encountered with this idea (Table 2). In addition, the description of evolution as a metamorphosis was also frequently encountered. Metamorphosis in biology is the process of change a living organism goes through during its existence (for example, egg-larva-butterfly). Alteration and metamorphosis are two biological terms for the same meaning in Turkish. The term metamorphosis, defined as a living organisms' accomplishment of developing through a profound physical change throughout its life-cycle, was frequently observed in the sentences describing evolution.

Another misconception encountered was some of the preservice teachers' assumptions that evolutionary and creation theories are opposing views. The perception is noted that if someone accepts one of these two polar ideas, perceived as the alternative to the other, then the other should be rejected was a dominant view of the preservice teachers. 
Table 2. Examples and frequencies of the most frequently observed misconceptions

\begin{tabular}{lll}
\hline Misconception & Frequency & Example sentence \\
\hline $\begin{array}{l}\text { Students explaining evolution as } 14 \\
\text { gaining better characteristics }\end{array}$ & & $\begin{array}{l}\text { Evolution is a change necessary to reach perfection. } \\
\text { Evolution is a change that increases the number of dominant } \\
\text { species, the extinction of weak species over time; this has } \\
\text { been the situation from the beginning of life. } \\
\text { Species, which are adapted to their biotope, are dominant, } \\
\text { and like the competition, are always popular. }\end{array}$ \\
\hline
\end{tabular}

Students explaining evolution with $13 \quad$ Evolution is a science defending that human beings came a human-related perspective into existence from apes, because evolution is change.

Evolution is Darwin, because it reminds me of the transition from apes to humans.

Students explaining evolution as a $10 \quad$ To me, evolution is chemical and physical changes living change a living being/organism beings go through from birth to death.

goes through during life

To me, evolution is the change of living beings over time, because each living being is born, grows, and changes.

Students explaining evolution with 9 metamorphosis

Evolution is change, metamorphosis, and adaptation, because biotope and environmental conditions change.

Evolution is the change created from one generation to other, because its definition is parallel with metamorphosis.

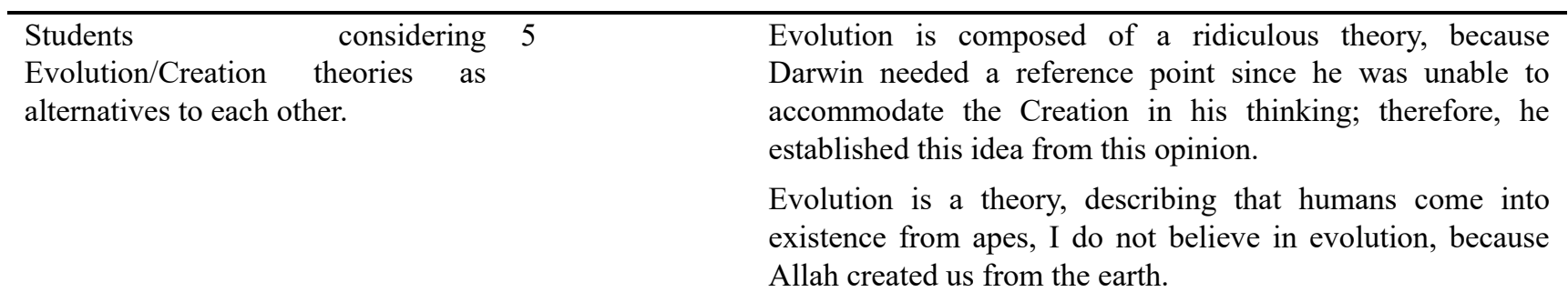

\section{Discussion}

Misconception is a problem when teaching difficult topics, which is also is apparent in the teaching of evolution. The results of the study showed that the rate of students with misconceptions is high among students who have not taken the evolution course. This result might imply that the lack of knowledge or superficial knowledge of evolution results in both the rejection of evolution and misconceptions related to evolution. Studies have reported that as conceptual understanding improves, the rate of rejection diminishes and the number of misconceptions decreases (Glaze et al., 2015; Deniz et al., 2008; Deniz \& Sahin 2016). Table 1 illustrates that as the level of knowledge increases, the number of misconceptions decreases. Nonetheless, despite the increase in knowledge level about evolution, some misconceptions remained in students who had completed the evolution course. In fact, researchers have frequently argued that it is difficult to correct and clear up misconceptions (Nehm \& Schonfeld, 2007a). Additionally, the high number of misconceptions encountered in students who had not taken the evolution course might also indicate that evolution education provided at the secondary and high school level creates misconceptions (Table 1). Further studies can clarify this point.

Another response was the idea that living beings always, in line with their needs, evolve to a stronger, better, and more perfect being was a frequently encountered misconception. Some students even described evolution as the effort to always reach perfection. On the contrary, this inaccurate perception is not the situation in nature. In nature, descriptions like good, positive, or negative are subject to change depending on the circumstances. A living organism, despite being a simple organism, can sometimes gain an advantage completely due to chance, thus, live in better conditions and reproduce more. The organism does not necessarily put extra effort in gaining this advantage (Futuyma, 2008). Evolution should not be regarded as a bitter struggle among living beings. The current misconception that evolution occurs as a result of bitter competition and struggle among living beings has been reported by many researchers (Nehm 
\& Schonfeld, 2008; Crawford, Zembal-Saul, Munford, \& Friedrichsen, 2005). It has also been stated that the misconception that only the strong survive and that living things go through adaptation in line with their needs are encountered among secondary school students (Abrie, 2010; Crawford, Zembal-Saul, Munford, \& Friedrichsen, 2005; Zuzovsky, 1994; Nehm \& Schonfeld, 2008; Bishop \& Anderson, 1990). It has been shown that graduate biology students have explained the evolutionary processes with a deterministic perspective (Zaim-Idrissi et al., 1993). This common misconception, observed at different educational levels from secondary to university level and in different countries, might indicate that both evolution and the nature of living things are not fully understood. It should be considered that natural selection and adaptation are difficult concepts to understand around the globe. Studies have revealed that teachers have similar misconceptions (Aleixandre, 1994; Nehm, Kim, \& Shepard, 2009; Nehm \& Schonfeld, 2007b). Other studies have pointed out that preservice teachers do not give up their misunderstandings even after completing research-based evolution courses (Rutledge \& Warden, 2000). The results of this study also supported this finding in the preservice teachers. Nehm and Shonfeld (2007b) have conducted an instructive study to clear up the misconceptions of some preservice science teachers. They reported that the preservice teachers' misconceptions decreased in number but did not cease to exist. All of these studies as well as this study's results were consistent. Teachers have insufficient knowledge of the evolutionary theory (Nunez 2012, Rutledge \& Warden, 2000), of natural selection (Nunez, 2012, Anderson, Fisher, \& Norman, 2002), and of fundamental mechanisms of macroevolution (Catley, 2006; Nunez, 2012). Abrie (2010) mentioned that teachers with misconceptions most likely transmit these misconceptions to their students, which results in diverse problems ranging from students' lack of understanding to the rejection of evolution. Teachers have difficulties in identifying students' evolution-related misconceptions (Aleixandre, 1994). Studies have found that teachers themselves can have misconceptions, that they are not generally aware of their students' misconceptions, and that even if they are, they are unable to alter their teaching strategies accordingly (Halim $\&$ Meerah, 2002). For this reason, teachers can not correct misconceptions and therefore cause the transfer of similar misconceptions to new generations in the educational process. This problem can be one of the underlying reasons for the misconceptions revealed in both this study and other studies commonly found across the world.

The sole human-focused perspective of evolution was another misconception frequently observed. This perspective is attributed to the information about the creation of human beings stated in sacred texts as an absolute fact. Similarly, this study has reported the belief that human beings were created superior and separate was the reason for the rejection of evolution (Blackwell et al., 2003). The underlying reason for this result might be accepting the creation of human beings depicted in sacred texts as a scientific fact, rather than perceiving it as a metaphor. Furthermore, studies conducted on this issue noted a tendency to accept the evolution of some plants and animals, despite a sharp objection to human evolution from students as well as society (Miller et al., 2006; Blackwell et al., 2003). The origin of humans constituted the main source of conflict in accepting the theory of evolution, resulting from the belief that we, as humans, are closer to a higher sacred being compared to other living beings or are created special (Blackwell et al., 2003). However, evolution does not conflict with the creation belief. Believing in evolution does not mean rejecting the creation belief, or vice versa. In fact, there are some metaphors in sacred texts describing evolution as humans were created from the earth and woman was created after man (gender evolution).

The misconception that evolution refers to a living being consciously changing to adapt to changing life conditions throughout was encountered in 14 out of the 190 students. Similar misconceptions were found in other studies (Mpeta, 2014; Nehm \& Schonfeld, 2008; Bishop \& Anderson, 1986; Bishop \& Anderson, 1990; Crawford et al., 2005). Lamarck's understanding of evolution, which is taught at the secondary school level, explains the change species go through for adaptation at the level of organisms, not at the level of species, which causes misconceptions. From this, students might pose questions like "why do living organisms close to caves not lose their sight, and can they develop new abilities, why can we not try this, and why do apes today transform to humans?" The knowledge that the organism never changes throughout its lifetime and the change occurs at the level of population can only be understood by students who take a comprehensive evolution course. Indeed, some students in this study, who took the evolution course, accurately identified evolution as the change of populations.

Some students' description of evolution as a metamorphosis was also encountered frequently. However, metamorphosis in biology is the stages from egg to larva to adult that a living organism goes through. For example, frog larva lives in water and its morphologies are similar to small fish, while adult ones are terrestrial and their morphologies have nothing in common with larva of the same species. Some students described evolution by using the metamorphosis term, which might stem from the fact that metamorphosis is synonymous with change in Turkish. In fact, Alters et al. (2002) has expressed this problem, reasoning that the daily and scientific use of some evolution related terms are different from each other. For example, the daily use of the English words, adapt, adaption, and fitness are different from their scientific use; misconceptions related to these words has been determined (Bishop \& Anderson, 1986; Alters et al., 2002). Similar to explaining evolution with the Lamarckian theory, explaining evolution with the metamorphosis term 
indicates that the student has an understanding that an organism changes throughout life. This reasoning not only points outs misconceptions related to evolution but also underlines an in sufficient comprehension of fundamental genetics and the genetic process. Genetics and evolution are related topics and a lack of understanding of genetics results in difficulty in learning and understanding evolution. Nineteen of the 190 students in this study believed that an organism evolves due to changing circumstances throughout the life-cycle. This misconception was encountered among $10 \%$ of the students, which can be considered quite high. No living organisms in nature perform a conscious or unconscious change either naturally or on purpose during the course of life from birth to death. A living being is born with inherited genetic characteristics. These genetic characteristics, managed by the living being are exposed to nature. These genetic characteristics in death are the same as in creation. Living organisms can keep pace with change, within tolerance, when the circumstances are changed. When a change challenges the tolerance boundaries of the living being it dies. Therefore, the organism does not have a chance to adapt itself to changing circumstances. What is changed after natural selection is not the organism itself, but the characteristics of that species' population. Therefore, a living being's conscious adaptation or its effort to adapt to changing circumstances is not the focus. Tekkaya and Kilic (2012) also determined that the changes in population characteristics are explained with the Lamarckian theory. Other researchers have also highlighted that the Lamarckian theory of evolution is latently dominant in students' explanations of evolution (Zuzovsky, 1994; Bishop \& Anderson, 1986). Nehm and Schonfeld (2017b) have stated that based on teachers' incorrect responses regarding evolution and natural selection in accurate ideas like the Lamarckian theory remain in grained even among teachers from diverse cultures and educational systems.

Modern Evolutionary Synthesis, which is today accepted as the valid evolutionary theory, is distant from the one offered by Darwin. However, evolution is still identified with Darwin's theory and Darwinism (Futuyma, 2008; Freeman \& Herron, 2002; Sanders \& Makotsa, 2016), which implies that the modern evolutionary synthesis is not sufficiently emphasized in textbooks and evolution education. Some students in this study explained evolution with a direct reference to Darwin and put forward interpretations only related to Darwin (Table 2). Modern evolutionary synthesis is different from Darwin's theory of evolution. Students' emphasis on Darwin is another indicator of their nodding acquaintance with evolution. The students identified with this misconception have not taken the evolution course. These results show that the modern evolutionary synthesis should be emphasized more at the secondary educational level.

Another reason for the large number of misconceptions in teaching evolution is that this topic is more difficult when compared to other topics in biology. Understanding the mechanisms of evolution can only be successful after learning many other independent fundamental topics. Creating this fundamental comprehension in students, contrary to other topics in biology, requires a large amount of knowledge and background; therefore, it is a difficult process for both the teacher and the student. Teachers may accept that every student understands the entire process completely but facts reflect otherwise. Therefore, it is normal to encounter misconceptions in students as acquiring knowledge of evolution which constitutes a scope of a course, rather than a single topic or unit. For example, the topic of the circulatory system or photosynthesis can be understood in a few lessons but understanding evolution requires an understanding of a wide range of disciplines (systematics, genetics, anatomy, etc.) as well as comprehensive evolutionary education. Therefore, it is difficult to sufficiently understand evolution at the secondary and high school educational level. The educational process idealized by the teacher is not valid for every student. No matter how well the topic or lesson is taught, the desired level of comprehension may not be achieved due to students' individual differences (interest/uninterested/having or not having a sense of wonder). Considering these differences, encountering a large number and types of misconceptions in a topic like evolution is understandable. To address these problems not only in the teaching of evolution but also in other courses, there is a need for effective, evidence-based pedagogic applications for all teachers and students. This can help to determine and clear up misconceptions, and obtain accurate scientific knowledge. One way to improve the quality of teachers, especially preservice teachers, is to help them to gain the capacity to always question misconceptions and to work with their colleagues and educators to recognize and minimize misconceptions in biology (Gomez-Zwiep, 2008). Studies have shown that all teachers should address their misconceptions, and be supported in teacher education programs to effectively help their students (Burgoon et al., 2011). Higher education programs in science should be proactive in helping preservice teachers develop effective applications to break the cycle of misconceptions, and determine, minimize, and enhance the possibility of eliminating misconceptions (Asay \& Orgill, 2010; Driver et al., 2000).

In conclusion, evolution occurs in every living population and should be emphasized in the design of textbooks or teaching evolution courses. The characteristics an organism possesses at birth will not change, but that populations will change over different generations with time, should be emphasized. Animations or applications demonstrating that natural selection and adaptation occurs at the population level are fundamental. Furthermore, particular attention should be focused on the misconception that evolutionary and creation theories are not opposing theories, believing in one does 
not mean rejecting the other. It should be emphasized that it is not accurate to perceive evolution as a living organisms' process to perfection and that living organisms do not have such a will or conscious.

\section{References}

Abraham, J. K., Meir, E., Perry, J., Herron, J. C., Maruca, S., \& Stal, D. (2009) Addressing undergraduate student misconceptions about natural selection with an interactive simulated laboratory. Evo Edu Outreach, 2, 393-404. https://doi.org/10.1007/s12052-009-0142-3

Abrie, A. L. (2010). Student teachers' attitudes towards and willingness to teach evolution in a changing South African environment. Journal of Biological Education, 44(3), 102-107. https://doi.org/10.1080/00219266.2010.9656205

Aleixandre, (1994). Teaching evolution and natural selection: a look at textbooks and teachers. Journal of Research in Science Teaching, 31(5), 519-535. https://doi.org/10.1002/tea.3660310507

Alters, B. J., \& Alters, S. M. (2001). Defending evolution: a guide to the creation/ evolution controversy. Sudbury, MA: Jones \& Bartlett.

Alters, B. J., \& Nelson, C. E. (2002). Perspective: Teaching evolution in higher education. Evolution, 56(10), 1891-1901. https://doi.org/10.1111/j.0014-3820.2002.tb00115.x

Anderson, D. L., Fisher, K. M., \& Norman, G. J. (2002). Development and evaluation of the conceptual inventory of natural selection. Journal of Research in Science Teaching, 39(10), 952-978. https://doi.org/10.1002/tea.10053

Anderson, R. D. (2007). Teaching the theory of evolution in social, intellectual and pedagogical context. Science Education, 91, 664-677. https://doi.org/10.1002/sce.20204

Asay, L. D., \& Orgill, M. K. (2010). Analysis of essential features of inquiry found in articles published in The Science Teacher '1998-2007'. Journal of Science Teacher Education, 21(1), 57-79. https://doi.org/10.1007/s10972-009-9152-9

Bishop, B. A., \& Anderson, C. W. (1990). Student conceptions of natural selection and its role in evolution. Journal of Research in Science Teaching, 27, 417-425. https://doi.org/10.1002/tea.3660270503

Blackwell, W. H., Powell, M. J., \& Dukes, G. H. (2003). The problem of student acceptance of evolution. Journal of Biological Education, 37(2), 58-67. https://doi.org/10.1080/00219266.2003.9655852

BouJaoude, S., Wiles, J., Asghar, A., \& Alters, B. (2011). Muslim Egyptian and Lebanese students' conceptions of biological evolution. Science \& Education, 20(9), 895-915. https://doi.org/10.1007/s11191-011-9345-4

Burgoon, J. N., Heddle, M. L., \& Duran, E. (2011). Re-examining the similarities between teacher and student conceptions about physical science. Journal of Science Teacher Education, 21(7), 859-872. https://doi.org/10.1007/s10972-009-9177-0

Catley, K. M. (2006). Darwin's missing link-a novel paradigm for evolution education. Science Education, 90, 767-783. https://doi.org/10.1002/sce.20152

Coll, R. K., \& Treagust, D. F. (2003). Investigation of secondary school, undergraduate, and graduate learners' mental models of ionic bonding. Journal of Research in Science Teaching, 40(5), 464-486. https://doi.org/10.1002/tea.10085

Crawford, B. A., Zembal-Saul, C., Munford, D., \& Friedrichsen, P. (2005). Confronting prospective teachers' ideas of evolution and scientific inquiry using technology and inquiry-based tasks. Journal of Research in Science Teaching, 42(6), 613-637. https://doi.org/10.1002/tea.20070

Dagher, Z. R., \& Boujaoude, S. (2005). Students' perceptions of the nature of evolutionary theory. Science Education, 89(3), 378-391. https://doi.org/10.1002/sce.20054

Deniz, H., \& Sahin, E. A. (2016). Exploring the factors related to acceptance of evolutionary theory among Turkish preservice biology teachers and the relationship between acceptance and teaching preference. Electronic Journal of Science Education, 20(4), 21-43.

Deniz, H., Donelly, L. A., \& Yilmaz, I. (2008). Exploring the factors related to acceptance of evolutionary theory among Turkish preservice biology teachers: Toward a more informative conceptual ecology for biological evolution. Journal of Research in Science Teaching, 45(4), 420-443. https://doi.org/10.1002/tea.20223

Dobzhansky, T. (1973). Nothing in biology makes sense except in the light of evolution. The American Biology Teacher, 35, 125-129. https://doi.org/10.2307/4444260

Driver, R., Newton, P., \& Osborne, J. (2000). Establishing the norms of scientific argumentation in classrooms. Science 
Education, 84(3), 287-312. https://doi.org/10.1002/(SICI)1098-237X(200005)84:3<287::AID-SCE1>3.0.CO;2-A

Evans, E. M. (2001). Cognitive and contextual factors in the emergence of diverse belief systems: Creation versus evolution. Cognit Psychol, 42(3), 217-66. https://doi.org/10.1006/cogp.2001.0749

Freeman, S., \& Herron, J. C. (2002). Evrimsel Analiz. Ankara: Palme Yayıncıllk.

Futuyma, D. J. (2008). Evrim, Ankara: Palme Yayınc1lik.

Garnett, P. J., \& Treagust, D. F. (1990). Implications of research on students' understanding of electrochemistry for improving Science curricula and classroom practice. International Journal of Science Education, 12(2), 147-156. https://doi.org/10.1080/0950069900120203

Glaze, A. L., Goldston, M. J., \& Dantzler, J. (2015). Evolution in the southeastern USA: Factors influencing acceptance and rejection in pre-service science teachers. International Journal of Science and Mathematics Education, 13, 1189-1209. https://doi.org/10.1007/s10763-014-9541-1

Gomez-Zwiep, S. (2008). Elementary teachers' understanding of students' science misconceptions: Implications for practice and teacher education. Journal of Science Teacher Education, 19, 437-454. https://doi.org/10.1007/s10972-008-9102-y

Halim, L., \& Meerah, S. M. (2002). Science trainee teachers' pedagogical content knowledge and its influence on physics teaching. Research in Science \& Technological Education, 20, 215-225. https://doi.org/10.1080/0263514022000030462

Kagan, T., \& Sanders, M. (2013). Use of confidence scales in analysing unscientific ideas about evolution among religious Jewish students. African Journal of Research in Mathematics, Science and Technology Education, 17(1-2), 38-49. https://doi.org/10.1080/10288457.2013.826969

Karatas, A. (2019). Opinions of pre-service teachers about evolution. Journal of Education and Training Studies, 7(8). https://doi.org/10.11114/jets.v7i8.4284

Kurt, H., Ekici, G., Aktaş, M., \& Aksu, O. (2013). On the concept of "respiration”: Biology student teachers' cognitive structure and alternative conceptions. Educational Research and Reviews, 8(21), 2101-2121.

Lerner, L. S. (2000). Good and bad science in the states. Thomas B. Fordham Foundation, 1627 K Street, N.W., Suite 600 , Washington, DC.

Mazur, A. (2004). Believers and disbelievers in evolution. Politics Life Sciences; 23(2), 55-61. https://doi.org/10.2990/1471-5457(2004)23[55:BADIE]2.0.CO;2

McComas W. F. (2006). Investigating evolutionary biology in the laboratory. Dubuque, WI: Kendall/Hunt Publishing Company;

McComas, W. F., \& William F. (1994). Investigating Evolutionary Biology in the Laboratory. National Association of Biology Teachers, Reston, VA. ISBN-0-941212-15-7.

Merriam, S. B. (2009). Qualitative Research (third edition). USA: Jossey-Bass Publications.

Miller, J. D., Scott, E. C., \& Okamoto, S. (2006). Public acceptance of evolution. Science, 313, 765-766. https://doi.org/10.1126/science. 1126746

Moore, R., Froehle, A., Kiernan, J., \& Greenwald, B. (2006). How biology students in Minnesota view evolution, the teaching of evolution, and the evolution-creation controversy. The American Biology Teacher, 68 (5), 35-42. https://doi.org/10.1894/0038-4909(2006)68[e35:HBSIMV]2.0.CO;2

Mpeta, M., de Villiers J. J. R., \& Fraser, W. J. (2015). Secondary school learners' response to the teaching of evolution in Limpopo Province. South Africa. Journal of Biological Education, 49(2), 1-15. https://doi.org/10.1080/00219266.2014.914555

Nehm, R. H., \& Reilly, L. (2007a). Biology majors' knowledge and misconceptions of natural selection. Bio Science, 57(3), 263-272. https://doi.org/10.1641/B570311

Nehm, R. H., \& Schonfeld, I. (2008). Measuring knowledge of natural selection: a comparison of the CINS, and open-response instrument, and oral interview. Journal of Research Science Teaching, 45, 1131-1160. https://doi.org/10.1002/tea.20251

Nehm, R. H., \& Schonfeld, I. S. (2007b). Does increasing biology teacher knowledge of evolution and the nature of science lead to greater preference for the teaching of evolution in schools? Journal of Science Teacher Education, 18(5), 699-723. https://doi.org/10.1007/s10972-007-9062-7 
Nehm, R. H., Kim, S. Y., \& Sheppard, K. (2009). Academic preparation in biology and advocacy for teaching evolution: Biology versus non biology teachers. Science Education, 93, 1122-1146. https://doi.org/10.1002/sce.20340

Nunez, E. E., Pringle, R. M., \& Showalter, K. T. (2012). Evolution in the Caribbean classroom: A critical analysis of the role of biology teachers and science standards in shaping evolution instruction in Belize. International Journal of Science Education, 34(15), 2421-2453. https://doi.org/10.1080/09500693.2012.700529

Rutledge, M. L., \& Warden, M. A. (2000). Evolutionary theory, the nature of science and high school biology teachers: Critical relationships. American Biology Teacher, 62, 23-31. https://doi.org/10.1662/0002-7685(2000)062[0023:ETTNOS]2.0.CO;2

Sadler, T. D. (2005). Evolutionary theory as a guide to socio scientific decision making. Journal of Biology Education, 39(2), 68-72. https://doi.org/10.1080/00219266.2005.9655964

Sanders, M., \& Makotsa, D. (2016). The possible influence of curriculum statements and textbooks on misconceptions: the case of evolution. Education as Change, 20(1), 216-238. https://doi.org/10.17159/1947-9417/2015/555

Tekkaya, C., \& Kilıc, D. S. (2012). Pre-service biology teachers' pedagogical content knowledge regarding teaching evolution. Hacettepe University Journal of Education, 42, 4006-4017.

Thagard, P., \& Findlay, S. (2010). Getting to Darwin: Obstacles to accepting evolution by natural selection. Science \& Education, 19(6), 625-636. https://doi.org/10.1007/s11191-009-9204-8

Tidon, R., \& Lewontin, R. C. (2004). Teaching evolutionary biology. Genetics and Molecular Biology, 27(1), 124-131. https://doi.org/10.1590/S1415-47572004000100021

Yıldırım, A., \& Simsek, H. (2008). Sosyal Bilimlerde Nitel Araştırma Yöntemleri, Ankara: Seçkin Yayıncılık.

Yılmaz, F. (2016). Evolution perception with metaphors. Universal Journal of Educational Research, 4(4), 812-820. https://doi.org/10.13189/ujer.2016.040418

Zaim-Idrissi, K., De sautels, J., \& Larochelle, M. (1993). “The mapis the territory!” The viewpoints of biology students on the theory of evolution. Alberta Journal of Education Research, 39, 59-72.

Zuzovsky, R. (1994). Conceptualizing a teaching experience on the development of the idea of evolution: An epistemological approach to the education of science teachers. Journal of Research in Science Teaching, 31(5), 557-574. https://doi.org/10.1002/tea.3660310509

\section{Copyrights}

Copyright for this article is retained by the author(s), with first publication rights granted to the journal.

This is an open-access article distributed under the terms and conditions of the Creative Commons Attribution license which permits unrestricted use, distribution, and reproduction in any medium, provided the original work is properly cited. 